\title{
O fim dos intelectuais acadêmicos... e o surgi- mento de outros
}

BIANCHETTI, Lucídio; VALLE, lone Ribeiro; PEREIRA, Gilson Ricardo de Medeiros Pereira. O fim dos intelectuais acadêmicos? Induções da Capes, desafios às associações científicas e a emergência do intelectual institucionalizado. Campinas: Autores Associados, 2015.

Tiago Ribeiro Santos Universidade Federal de Santa Catarina

fim dos intelectuais acadêmicos? poderia pertencer ao índex de li-vros provocadores - seja em virtude da pergunta em seu título ou de seu for-mato de bolso característico às obras de intervenção pública. Lucídio Bianchetti, lone Ribeiro Valle e Gilson Ricardo de Medeiros Pereira, pesquisadores e professores universitários, abordam a possibilidade do fim do intelectual acadêmico - responsável maior pela produção científica. De fato o fim dos 274 intelectuais acadêmicos se trata antes de uma dúvida: por isso não conviria tratar do fim do intelectual lato senso mas sim observar transformações que ele estaria sofrendo no contexto científico brasileiro.

Os intelectuais acadêmicos não estariam deixando de produzir ciên-cia - pelo contrário - eles seriam ainda mais produtivos segundo forças regu-ladoras que atuariam em nível global, induzindo eles a obedecerem a pa-drões internacionais de produção científica através de um racionalismo de mercado. $\bigcirc$ racionalismo de mercado produziria coerções que se imporiam sobre os agentes do campo científico, reduzindo as chances de trabalhos in-ventivos em nome de um modo de fazer ciência que visaria lucros imediatos, objetivos, contabilizáveis. O sentido de fazer ciência - nos dois sentidos da pa-lavra, de direção e de significado - se transformaria assim segundo uma lógi-ca de concorrência imposta de fora para dentro: ela influenciaria inclusive associações científicas engajadas em manter condições de trabalho favorá-veis ao avanço da ciência.

$\bigcirc$ livro não se trata porém de um relato de veteranos que possivel-mente sentem na própria pele as pressões do campo científico: ele se trata de um exercício de compreensão de um fenômeno cujo poder - como os 
auto-res escrevem - "é maior do que os esforços de teorização das Ciências Hu-manas e Sociais". $\bigcirc$ apoio teórico elencado pelos autores se apresenta desde cedo através da obra de Pierre Bourdieu (1 930-2002) e que, somada a uma extensa lista de outras referências, procura se prevenir contra a impressão de um sincretismo teórico.

Bianchetti, Valle e Pereira apreendem ao menos três grupos de agen-tes identificados ao campo científico brasileiro: as associações científicas, os órgãos avaliadores da produção intelectual - em particular medida a Coor-denação de aperfeiçoamento de pessoal de nível superior (Capes) - e pes-quisadores, jovens pesquisadores, professores e estudantes. Os três podem ser considerados agentes de um estado do campo cujas regras de entrada, de permanência e de exclusão são pouco a pouco transformadas, para não di-zer deformadas, ao passo em que ele opera mensurando o valor do trabalho científico.

Um efeito do tal estado do campo seria a estandardização da produ-ção científica: uma vez que a ciência se torna um produto ela passa a se des-tinar a diferentes clientelas compreendendo desde jovens estudantes a pes-quisadores que - sem espaço para divulgar artigos em periódicos de renome - seriam atraídos pela promessa de publicação imediata em periódicos ge-ralmente desconhecidos ou que exigem pagamento para veicular suas pro-duções. O que preza a lei de mercado, afinal, não seria o princípio de que para todo o tipo de produto podemos encontrar igualmente um grupo de clientes em específico? $\bigcirc$ que explicaria a evasão geralmente nos últimos dias de congressos se não houvesse mais pessoas dispostas a comunicar que a ouvir uma comunicação? $\bigcirc$ "turismo de eventos" não seria um novo produto engendrado pelo campo científico?

Interrogações como essas derivam do princípio de que inclusive os menores esforços obtêm suas devidas recompensas e seus relativos desta-ques. Autores da envergadura de um Walter Benjamin (1892-1940) e Norbert Elias (1897-1990) - por exemplo - por isso poderiam ser considerados improdu-tivos, inviáveis ao campo científico, uma vez que permaneceram longos anos em silêncio até que pudessem trazer à luz suas obras maiores, as pedras angu-lares de seus próprios pensamentos. $\bigcirc$ intelectual acadêmico se torna assim alguém com mais gosto pelo resultado que pelo processo: um agente que segundo uma lei de mercado anteciparia as possibilidades de lucros e de ris-cos. Representada pela expressão publique ou pereça! a emergência de 
um novo tipo de intelectual seria inerente então a instabilidades permanentes: elas tenderiam a desencorajar projetos de longo prazo à medida que esse in-telectual não encontrasse adesão de órgãos financiadores.

$\bigcirc$ fim dos intelectuais acadêmicos não supõe porém o fim do campo científico, mas a escalada de normatividades comprometidas em induzir a produção científica, atribuindo ao campo a qualidade de um jogo em que as regras assumem a característica de transparentes e justas, atuando tanto em nome da pena quanto da recompensa.

$\bigcirc$ homo academicus cujos intelectuais representam são também homo ludens: homens e mulheres atraídos pelo jogo proposto pelo campo. $\bigcirc$ sentido bourdesiano do conceito de illusio - utilizado pelos autores para tor-nar inteligível a permanência de um espírito de jogo no campo acadêmico - supõe que os campos do mundo social, quaisquer que sejam eles, ainda que se tratem dos campos mais alheios a nós mesmos como os campos da filatelia e da tauromaquia, são indissociáveis de uma espécie de força de atração que move os indivíduos a agirem em nome de bens comuns e que, em dispu-ta, configuram tanto formas de cooperações quanto de concorrências. Os campos sociais apenas deixam de existir quando os interesses se esfriam; quando bens

276 materiais e simbólicos em disputa se tornam menos apetecedo-res.

No Brasil o campo científico ironicamente estaria aquecido ao dispor de estimulantes como rankings nacionais e médias de produtividade que animariam a competição entre seus agentes. $\bigcirc$ fato é que tendo uma pro-dução média o intelectual institucionalizado corre o risco de se tornam um in-telectual médio - e é justamente esse rebaixamento que iria na contramão da qualificação do trabalho científico.

Bianchetti, Valle e Pereira fazem da imposição da produção científica um objeto de pesquisa pelo qual eles intervêm e se posicionam no campo. Ritmada e quantificada a produção cientifica tenderia a se decompor em partes perdendo de vista o seu todo. Essas e outras reflexões fazem d' $O$ fim dos intelectuais acadêmicos? um livro a ser lido ao mesmo tempo com cal-ma e urgência. 
Ms. Tiago Ribeiro Santos

Universidade Federal de Santa Catarina Laboratório de Pesquisas Sociológicas Pierre Bourdieu | CNPQ Doutorando do Programa de Pós-Graduação em Educação E-mail | tiago.ribeiro@live.com

Recebido 15 mar. 2016 Aceito 31 out. 2016 